\title{
Scintillation characteristics of deformed large-sized Nal crystals
}

\author{
V.V.Shlyakhturov, A.V.Gektin, A.Yu.Boyarintsev, V.I.Taranyuk \\ Institute for Single Crystals, STC "Institute for Single Crystals", \\ National Academy of Sciences of Ukraine, \\ 60 Lenin Ave., 61001 Kharkiv, Ukraine
}

Received October 18, 2013

\begin{abstract}
The effect of plastic deformation on defect structure and functional parameters of Nal based crystals and scintillator $\mathrm{Nal}(\mathrm{TI})$ in particular has been studied. Plastic flow modeling in decorated samples as well as in large size crystal blanks demonstrated significant non uniformity of the deformation map along the sample. Scintillation parameters (light output and energy resolution) are practically the same through the whole crystal volume. Post deformation scintillation parameters are similar to the single crystal ones. This phenomenon is typical for the wide range of temperature and deformation rates for this type of crystals.
\end{abstract}

Изучено влияние пластической деформации на структуру дефектов и функциональные параметры кристаллов типа Nal и сцинтилляторов $\mathrm{Nal}(\mathrm{TI})$, в частности. Моделирование пластического течения как на декорированных образцах, так и в кристаллических заготовках большого размера показало значительную неравномерность картины деформации образцов. Сцинтилляционные параметры (световыход и энергетическое разрешение) практически одинаковы по всему объему кристалла. Сцинтилляционные параметры деформированных и монокристаллических образцов совпадают. Это явление характерно для широкого диапазона изменений температуры и степени деформации данного типа кристаллов.

Сиинтиляційні характеристики деформованих кристалів Nal великих розмірів. В.В.Шляхтуров, О.В.Гектін, А.Ю.Бояринцев, В.І.Таранюк.

Вивчено вплив пластичної деформації на структуру дефектів і функціональні параметри кристалів типу $\mathrm{Nal}$ і сцинтиляторів $\mathrm{Nal}(\mathrm{TI})$, зокрема. Моделювання пластичної течії як на декорованих зразках, так і в кристалічних заготовках великого розміру показало значну нерівномірність картини деформації зразків. Сцинтиляційні параметри (світловий вихід і енергетична роздільна здатність) практично однакові повз всього об'єму кристала. Сцинтиляційні параметри деформованих і монокристалічних зразків збігаються. Це явище характерне для широкого діапазону змін температури і ступеня деформації даного типу кристалів.

\section{Introduction}

Parameters of many scintillation materials and detectors are formed by modification of their crystal structure from single crystal to polycrystal (including ceramic materials [1], films [2, 3], etc.) [4]. For isotropic materials differences in luminescence mechanisms and efficiency could be ob- served only within the limits of light scattering and absorption on the grain boundaries and structure defects. However, a priori it is practically impossible to estimate their function. On the one hand, there are cases when ultrafinely-divided ceramics have light yield which is close to theoretical limit $[5,6]$ in spite of developed boundary system and great number of scattering centers. On the other 
hand, in some cases even insignificant structure damages degrade importantly the quality of scintillation detector [4].

In many cases deformation is a method of imparting special properties to material (strengthening, particular shapes, large size - Polyscin Nal(TI)[7]). However, features of changes in scintillation characteristics are still poorly studied. At the same time alkali halide crystals allow performing deformation in wide range of temperatures and deformations [8, 9].

The present work is devoted to the analysis of changes in functional characteristics of $\mathrm{Nal}$ polycrystalline scintillators which are produced by method of press forging [8] in different shapers. These conditions allow producing detectors with optimal shapes and parameters.

\section{Experimental}

Nal single crystals grown by continuous growth technique [10] or skull method [11, 12] were used for the study. Single crystal samples of $2 \mathrm{~cm}$ to $6 \mathrm{~cm}$ height were used to simulate conditions of deformation. It is known that parameters of deformation depend on sample shapes which are used in experiments [13]. Samples were deformed along crystallographic direction $<100>$ on deformation machine "Instron" by an axial pressing.

Large-sized samples were deformed on industrial hydraulic presses by 250 tons pressure. All facilities were supplied with furnaces to conduct high temperature deformation. Hydraulic presses were equipped with additional hydraulic pumps which provided controlled shift of cross-arm by devices of measuring of loading cross-arm shift within $0.2 \mathrm{~mm}$. Stress made to samples which were deformed on hydraulic press was calculated from pressure value in hydraulic system of press. Deformation was run at the rate of stock shift $0.2-1.0 \mathrm{~mm} / \mathrm{min}$, at temperature from $300^{\circ} \mathrm{C}$ to melting point.

The study of celles and dislocation structure was carried out in a dry box on fresh cleaved of samples. Acetic acid was used as selective etch. Polycrystals were cut out by filar saw and were previously polished on wet cloth. Final polishing was carried out after careful drying of samples in a dry box with application of mixture of isobutyl and ethyl alcohol. Fragmented structure of polycrystalline samples with misorientation of grains at more than 1-3 degrees was defined by means of etching of polished surfaces of samples by ethyl alcohol. Average

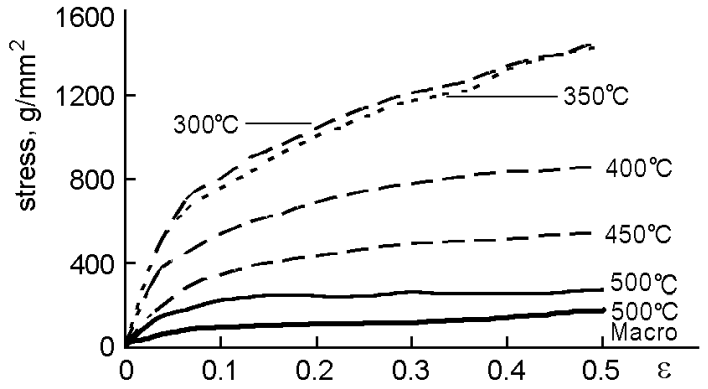

Fig. 1. Work hardening curves of Nal crystals within the range of temperatures $300-500^{\circ} \mathrm{C}$. Heavy line $\left(500^{\circ} \mathrm{C}\right.$ macro) shows the deformation curve measured for large-sized Nal crystal.

dimensions of grain was defined by secant method.

\section{Results}

Generally, diagrams of structural conditions of deformed alkali halide crystals are described in [14] and are very similar for different crystals. Nevertheless, first of all, we should consider the data on influence of temperature on plastic flow of Nal crystals. Fig. 1 shows work hardening curves of $\mathrm{Nal}$ samples (cubes with $30 \mathrm{~mm}$ side), deformed at the rate of $\varepsilon=3 \cdot 10^{-4} \mathrm{c}^{-1}$ along crystallographic direction $<100>$ within the range of intermediate temperatures from $300^{\circ} \mathrm{C}$ to $500^{\circ} \mathrm{C}$.

It should be noted that cracks generally appeared in the samples during the deformation process at $300-350^{\circ} \mathrm{C}$. Represented data indicate, that starting from $500^{\circ} \mathrm{C}$ deformation proceeds practically under steady-state conditions without cracks. But at the same time, as a result of recrystallization, dimensions of the grains increased to several centimeters.

Single crystal deformation in limited volume allows using crystalline material most effectively and reducing waste products. Therefore, the present approach is used for production of large-sized crystal blanks.

It is obvious, that plastic flow along the crystal is heterogeneous and this inhomogeneity should be estimated and simulated. Such approach was developed in [15] before for deformation of samples with spare lateral surfaces. Its main point is as follows. Specially prepared decorated samples produced by diffusion welding at $550^{\circ} \mathrm{C}$ of $5^{-}$ 7 plates cut out of crystals were used to determine flow direction of the material. A cylindrical sample $60 \mathrm{~mm}$ in diameter and height was produced from each decorated blank. A thin layer of graphite powder was placed between sintered plates to reproduce 

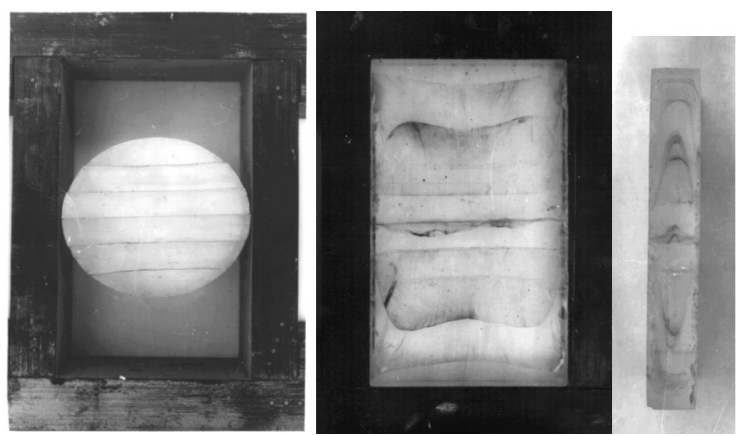

Fig. 2. Position of interface boundaries in initial sample before and after deformation when sample material filled the mold. On the right is a picture of cross-section of the sample.

boundaries. Deformation was held at $1.4 \cdot 10^{-4} 1 / \mathrm{c}$ rate in special metal mold (Fig. 2). This experiment was held in several stages to fix shift of crystal material stepwise, each stage showed a $10 \%$ deformation degree. After cooling the surface of samples was polished, lapped and photographed. Fig. 2 shows the shift of initial position of decorated sample in mold and final stage of filling of mold. Right picture shows cross-section area of the final sample.

The form of deformed surfaces shows, that maximum shift of material from the center of initial sample is directed to the mold corners. The maximum material shift is noted in the central part of the crystal. There is practically no shift of the material is in contact with upper and lower hobs.

Under the same conditions the crystal of the same dimensions was deformed from the whole crystal blank with misorientation of blocks to 1 degree to detect sell structure of samples which are produced during deformation. Dimensions of grains/sells of the formed polycrystals (deformation at $450^{\circ} \mathrm{C}$ ) was about 1-2 $\mathrm{mm}$. It should be noted that inspite of obvious inhomogeneity of the material flow, distribution of grains dimensions under different sections of sample is practically homogeneous.

Above mentioned experiments allow simulating parameters of residual deformation and transforming the approach for large-sized samples. Initial crystal dimensions $400 \mathrm{~mm}$ in diameter and $300 \mathrm{~mm}$ high was heated at rate of $5^{\circ} \mathrm{C} / \mathrm{h}$ to $500^{\circ} \mathrm{C}$ temperature to obtain full-scale polycrystalline blank. Deformation was held up to deformation degree of $50 \%$ at speed of $3 \cdot 10^{-6} \mathrm{c}^{-1}$.

As a result, a blank with $750 \mathrm{~mm}$ diagonal was obtained. The blank contained no cracks and looked optically homogenous. Intragranular structure was close to single

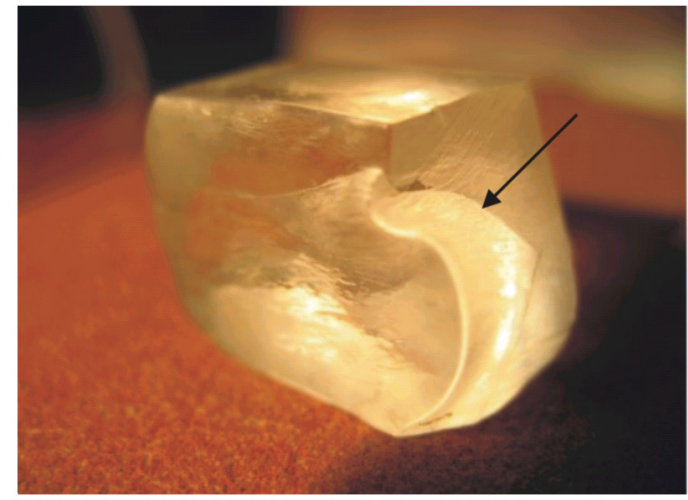

Fig. 3. A block sample after deformation at $T=$ $500^{\circ} \mathrm{C}$ to $\varepsilon=0.5$.

crystal structure with dislocation density around $10^{7} 1 / \mathrm{cm}^{2}$.

The transmission of polycrystalline blanks were practically unchanged and formed the same absorption coefficient $(k=$ $0.005 \mathrm{~cm}^{-1}$ ) in comparison with initial single crystals. Directed by deformation light scattering in $\mathrm{Nal}$ crystals was analyzed separately. Both single crystal samples and samples consisting of 2 or 3 misorientated to 10-20 degrees blocks were selected for the study. These samples were specially deformed (see conditions in section 2) for the analysis of the evolution of both border itself and optical characteristics of the crystal. Fig. 3 gives surface appearance of the sample after $50 \%$ deformation. It is seen (pointed by the arrow) that the border does not disappear, on the contrary, it increases misorientation angle to 34 degrees. However, on the whole, the clarity of the sample remains without changes.

Numerous runnings of the experiment showed that wide angle boundaries do not appear and originally existing boundaries do not disappear at the deformation at elevated temperatures. At the same time there is no their essential influence on optical characteristics of the crystals detected.

\section{Discussion}

On the whole, the analysis of the uniformity of scintillation characteristics along all cross-section of the sample is an issue of major interest. Heterogeneity of deformation distribution, described in section 3 , is a reason to test this fact. The known data on output modification and luminescence spectral composition in deformed crystals [16] allow supposing that their importance could be significant in this case also.

In the frame of the study 200 detectors of each type of crystal dimensions 
Energy resolution, $\mathrm{R}, \%$

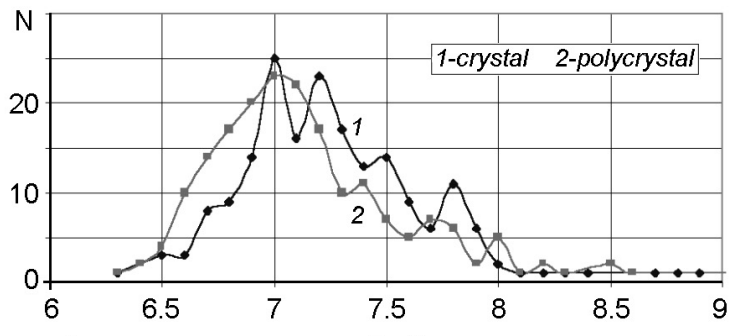

a)

$\mathrm{R}, \%$

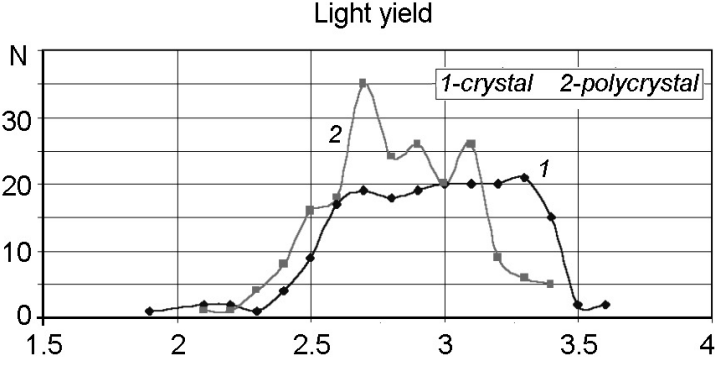

b)

L.Y., a.u.

Fig. 4. a) Comparison of energy resolution $R, \%$ of 200 polycrystalline and 200 single crystal detectors, $25 \times 25 \times 105 \mathrm{~mm}^{3} .{ }^{137} \mathrm{Cs}$ source. b) Comparison of light yield of 200 polycrystalline and 200 single crystal scintillators, $25 \times 25 \times 105 \mathrm{~mm}^{3}$.

$25 \times 25 \times 105 \mathrm{~mm}^{3}$ produced both of largesized single and polycrystals by similar method were cut and housed as standard scintillation detectors. According to one method light yield and energy resolution $(R, \%)$ were measured in these detectors. Fig. 4 gives these measuring data. Average values of $R$, is $7.33 \%$ for single crystal detectors and $7.31 \%$ for polycrystalline detectors are practically the same.

Average data for the light yield (arbitray units) are very close; 2.95 for single crystals and 2.83 for polycrystals.

The above data show that average meanings of scintillation parameters for detectors of similar dimensions produced of single crystal and polycrystalline blanks, coincide.

Thus, obtained data allow making several hypotheses. Either the deformation of $\mathrm{Nal}$ crystals does not lead to essential changes of defects concentration in crystals or mentioned defects are not active from the point of radioluminescence stimulation or quenching. One way or another, but obtained results point low sensitivity of halide scintillators to the deformation at elevate and high temperatures. This phenomenon underlies possibilities to modify crystal shape and dimensions in favor of numerous practical applications.

\section{Conclusion}

It is necessary to note that this study demonstrates ability to change the shape and size of Nal crystals by their transformation from single to polycrystalline state. Such transformation does not significantly change scintillation parameters that explain ability to use extruded and press forged crystal for different application. Specific tests of decorated samples in rectangular shaped mold allows to visualize non uniformity of the plastic glow at elevated tem- peratures that allows to increase sample hardness without deterioration of the main scintillation characteristics.

\section{References}

1. D.J.Wisniewski, L.A.Boatner, J.S.Neal et al., IEEE Trans. Nucl.Sci., 55, 1501 (2008).

2. V.V.Nagarkar, S.R.Miller, V.Gelfandbein et al., Nucl. Instrum. Meth. Phys. Res. A, 652, 271 (2011).

3. A.Gektin, A.Lebedinskiy, in book: "Scintillation Materials. Engineering, Devices, Application", Kharkov, ISMA (2009) [in Russian].

4. P.Lecoq, A.Annenkov, A.Gektin et al., Inorganic Scintillators for Detector Systems. Physical Principles and Crystal Engineering. Ser.: Particle Acceleration and Detection, Springer, New York (2006).

5. N.J.Cherepy, Z.M.Seeley, S.A.Payne et al., IEEE Tran. Nucl.Sci., 60, 2330 (2013).

6. Takayuki Yanagida, Kei Kamada, Yutaka Fujimoto et al., Opt. Mater., 35, 2480 (2013).

7. http://www.detectors.saint-gobain.com/Nal(TI)

8. B.C.Koepke, R.H.Anderson, R.J.Stokes, in: Deformation of Ceramic Materials, ed. by R.G.Brandt and R.E.Tressier, London (1975).

9. A.Yu.Boyarintsev, A.V.Gektin, V.A.Lotnik et al., Izvestiya Vysshikh Uchebnykh Zavedenii. Mater. Electron. Tekhn., 1, 28, (2004) [in Russian].

10. V.I.Goriletsky, V.A.Nemenov, L.G.Eidelman et al., J. Cryst. Growth, 52, 509 (1981).

11. V.Taranyuk, A.Gektin, I.Kisil et al., J.Cryst. Growth, 318, 820 (2011).

12. I.I.Kisil, V.I.Taranyuk, S.V.Yaroslavkin, Functional Materials, 15, 600 (2008).

13. Yu.Boyarintsev, A.V.Gektin, L.M.Soifer et al., Izvestiya Vysshikh Uchebnykh Zavedenii. Mater. Electron. Tekhn., 1, 21, (2000) [in Russian].

14. A.V.Gektin, L.G.Eidelman, Fiz.Tverd.Tela, 24, 1467 (1982).

15. A.Yu.Boyarintsev, A.V.Gektin, V.V.Shlakhturov, Functional Materials, 13, 608 (2006).

16. A.V.Gektin, N.V.Shiran, V.Ia.Serebryanuy et al., Opt.Spectr., 72, 1061 (1992). 